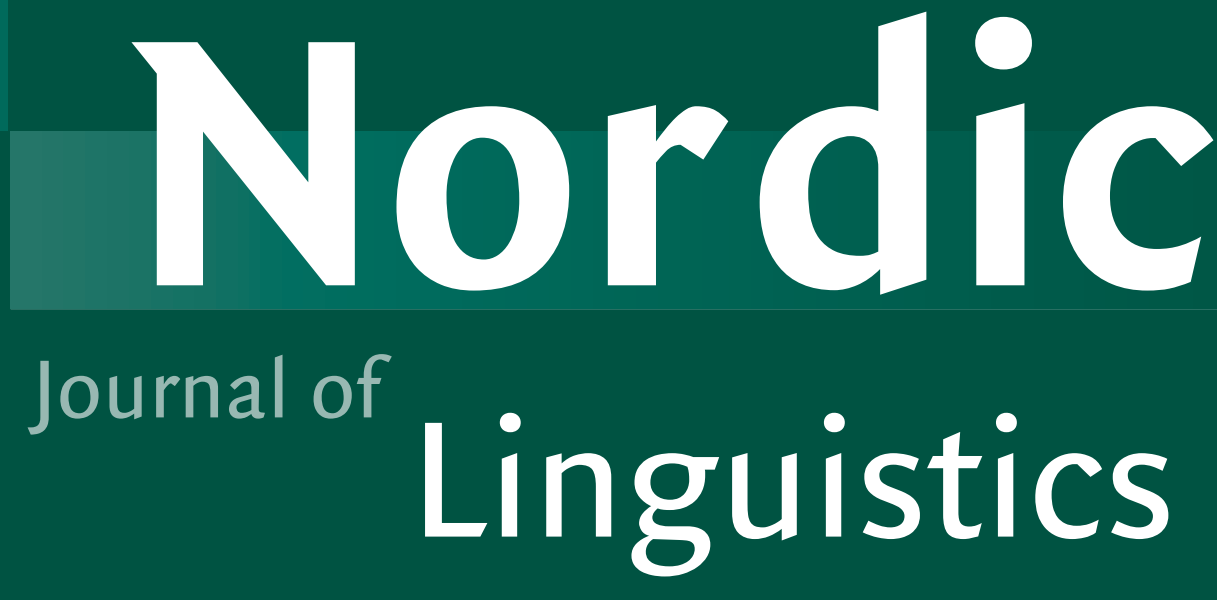

VOLUME $42 \cdot$ NUMBER $3 \cdot 12 / 19$

\title{
CAMbridge
} UNIVERSITY PRESS 


\section{Nordic Journal of Linguistics}

Published by Cambridge University Press for the Nordic Association of Linguists

Editors: Gunnar Ólafur Hansson (University of British Columbia), Marit Julien (Lund University), Matti Miestamo (University of Helsinki)

Review Editor: Fredrik Heinat (Linnæus University)

\section{Editorial Board}

\author{
Arto Anttila, Stanford \\ Johanna Barðdal, Bergen \\ Michael Barnes, London \\ Ute Bohnacker, Uppsala \\ Kersti Börjars, Manchester \\ Joan Bresnan, Stanford \\ Kristin Melum Eide, Trondheim \\ Elisabet Engdahl, Göteborg \\ Cathrine Fabricius-Hansen, Oslo \\ Thorstein Fretheim, Trondheim \\ Nina Grønnum, København \\ Anders Holmberg, Newcastle \\ Junko Itô, Santa Cruz \\ Eva Skafte Jensen, København \\ Per Anker Jensen, København
}

\author{
Janne Bondi Johannessen, Oslo \\ Henrik Jørgensen, Århus \\ Gunlög Josefsson, Lund \\ Satu Manninen, Lund \\ Urpo Nikanne, Åbo/Turku \\ Tomas Riad, Stockholm \\ Curt Rice, Oslo \\ Eiríkur Rögnvaldsson, Reykjavík \\ Pekka Sammallahti, Oulu \\ Peter Sells, York \\ Sigríður Sigurjónsdóttir, Reykjavík \\ John Tøndering, København \\ Naja Trondhjem, København \\ Maria Vilkuna, Helsinki \\ Eivind Weyhe, Tórshavn
}

\section{Editorial policy}

The Nordic Journal of Linguistics (NJL) is published by Cambridge University Press for the Nordic Association of Linguists. The journal covers all branches of linguistics, with a special focus on issues related to the Nordic languages (including Finnish, Greenlandic and Saami) and on issues of general theoretical interest. The editors encourage submission of research articles, short communications, book reviews and review articles. Each volume contains three issues, one of which is a thematic issue.

\section{Manuscript submission}

All submissions, including book reviews, must be made through the Manuscript Central site:

http://mc.manuscriptcentral.com/njl.

General queries concerning NJL should be sent to njleditors@cambridge.org.

Books for review and queries about review articles should be sent to:

Fredrik Heinat,fredrik.heinat@lnu.se

Department of Languages, Linnæus University, 35195 Växjö, Sweden

\section{Subscriptions}

Nordic Journal of Linguistics (ISSN 0332-5865) is published three times a year in May, October and December. Three issues form a volume. The subscription price of volume 42 (excludes VAT, but includes electronic access and postage) is $£ 175$ net (US\$277 in the USA, Canada and Mexico) for institutions; the electronic-only price available to institutional subscribers is $£ 144$ (US\$239 in the USA, Canada and Mexico). Single issues are $£ 67$ (US\$106 in the USA, Canada and Mexico). EU subscribers (outside the UK) who are not registered for VAT should add VAT at their country's rate. VAT-registered subscribers should provide their VAT registration number. Japanese prices for institutions are available from Kinokuniya Company Ltd, P.O. Box 55, Chitose, Tokyo 156, Japan. Prices include delivery by air. Members of the Nordic Association of Linguists receive the journal as part of their membership subscription (see inside of back cover). Orders, which must be accompanied by payment, may be sent to a bookseller, subscription agent or direct to the publisher: Cambridge University Press, Shaftesbury Road, Cambridge CB2 8RU; or in the USA, Canada and Mexico: Cambridge University Press, Journals Fulfillment Department, 1 Liberty Plaza, Floor 20, New York, NY, 10006, USA

This journal issue has been printed on FSC-certified paper and cover board. FSC is an independent, non-governmental, not-for-profit organization established to promote the responsible management of the world's forests. Please see www.fsc.org for information.

Printed in the UK by Bell \& Bain

(C) Nordic Association of Linguists 2019 